\title{
ANALISIS PERANAN PEMERINTAH DAERAH TERHADAP PEMBERDAYAAN MASYARAKAT KABUPATEN SIDENRENG RAPPANG (Studi Kasus Pengentasan Anak Putus Sekolah di Kecamatan Maritengngae)
}

\author{
${ }^{1)}$ Siti Hardianti Arkian, ${ }^{2)}$ Sahar, ${ }^{3)}$ Andi Feby Febriani \\ Fakultas ilmu sosial dan ilmu poltik Universitas Muhammadiyah Sidenreng Rappang \\ sitihardianti.arkian1992@gmail.com \\ saharkhan43111125@gmail.com \\ andifebyfebriani.0910580419062@gmail.com
}

\begin{abstract}
Abstrak
Penulisan ini bertujuan Untuk mengetahui pengaruh peranan pemerintah daerah terhadap pemberdayaan masyarakat pengentasan anak putus sekolah di Kecamatan Maritengngae Kabupaten Sidenreng Rappang dan untuk mengetahui pemberdayaan masyarakat dalam pengentasan anak putus sekolah di Kecamatan Maritengngae Kabupaten Sidenreng Rappang. Populasi dalam hal ini sebanyak 65 orang, sedangakan teknik pengumpulan data yang digunakan adalah Kuesioner, Dokumentasi, Observasi sedangkan Teknik analisis data yang digunakan yaitu analisis data dengan table frekuensi. Hasil dalam penulisan jurnal ini adalah Persiapan Sarana dan Prasarana untuk pelaksanaan Pembelajaran (Gedung Sekolah) adalah 95\% yang dengan kategori Sangat Setuju, Biaya Operasional yang diperuntukan dalam pelaksanaan pendidikan adalah73,5\% dengan kategori Sangat Setuju, Pemberdayaan Sumber Daya Manusia yaitu tenaga Pendidik dalam pelaksanaan pembelajaran adalah $77,25 \%$ yang berarti kategori Setuju, Pemberian bantuan berupa Pendidikan Gratis bagi yang tidak mampu mengakses Pendidikan Formal adalah $88,5 \%$ yang berarti kategori setuju, Program Wajib belajar 12 tahun untuk meningkatan dan mengembangan SDM dalam bidang Pendidikan adalah 66,25\% yang berarti kategori Setuju, Pengentasan anak putus sekolah merupakan akses kepada anak yang kurang mampu adalah $74,5 \%$ yang berarti kategori Setuju, usaha pemerintah terhadap peningatan SDM adalah $74,5 \%$ yang berarti kategori setuju.
\end{abstract}

Kata Kunci : Peranan dan Pemberdayaan

\begin{abstract}
This writing aims to determine the effect of the role of local government on community empowerment in alleviating school dropouts in the Maritengngae District, Sidenreng Rappang Regency and to determine community empowerment in alleviating school dropouts in the Maritengngae District, Sidenreng Rappang Regency. The population in this case is 65 people, while the data collection techniques used are questionnaires, documentation, observation, while the data analysis technique used is data analysis with a frequency table. The result in writing this journal is the preparation of facilities and infrastructure for the implementation of learning (school building) is 95\% in the category Strongly Agree, Operational costs allocated in the implementation of education are $73.5 \%$ with the category Strongly Agree, Empowerment of Human Resources, namely Educators in the implementation of learning is $77.25 \%$ which means the category Agree, Providing assistance in the form of Free Education for those who are unable to access Formal Education is 88 , 5\% which means the category agrees, the 12 year compulsory education program to improve and develop human resources in the education sector is $66.25 \%$ which means the category Agree, alleviating school dropouts is access to underprivileged children is $74.5 \%$ which means the category Agree, the government's effort to increase HR is $74.5 \%$ which means the category agrees.
\end{abstract}

Keywords: supervision and work discipline 


\section{A. PENDAHULUAN}

Kemajuan suatu negara sangat ditentukan dengan kualitas sumber daya manusia (SDM) yang dimilikinya. Semakin berkualitas SDM maka semakin maju dan sejahtera negara tesebut, sebagai contoh Jepang,Singapura, Malaysia,dan lainnya. Sedangkan,kualitas SDM ditentukan dengan kualitas pendidikan. Dengan demikian pendidikan yang berkualitas menjadi faktor penting bagi kemajuan suatu negara.Semakin berkualitas pendidikan maka semakin maju negara dan sebaliknya.

Pembukaan Undang-Undang Dasar Negara Republik Indonesia tahun1945 (UUD 1945) mengamanatkan bahwa Pemerintah Negara Indonesia harus melindungi segenap bangsa Indonesia dan seluruh tumpah darah Indonesia dan untuk memajukan kesejahteraan umum, mencerdaskan kehidupan bangsa, dan ikut melaksanakan ketertiban dunia yang berdasarkan kemerdekaan, perdamaian abadi dan keadilan sosial dengan demikian, Pemerintah diwajibkan untuk mengusahakan dan menyelenggarakan satu sistem pendidikan nasional bagi seluruh warga negara Indonesia. Sistem pendidikan nasional dimaksud harus mampu menjamin pemerataan kesempatan dan peningkatan mutu pendidikan, terutama bagi anak-anak, generasi penerus keberlangsungan dan kejayaan Bangsa dan Negara Kesatuan Republik Indonesia (NKRI).

Pendidikan merupakan salah nsatu faktor yang paling mendasar dalam siklus kehidupan manusia mulai lahir hingga akhir hayat Secara teori, Pendidikan adalah usaha sadar dan terencana untuk mewujudkan suasana belajar dan proses pembelajaran agar peserta didik secara aktif mengembangkan potensi dirinya untuk memiliki kekuatan spiritual keagamaan, pengendalian diri, kepribadian, kecerdasan, akhlak mulia, serta keterampilan yang diperlukan dirinya, masyarakat, bangsa dan Negara (UU Sisdiknas, 2003 : 1).

Selain itu, pendidikan adalah alat untuk merubah cara berpikir kita dari cara berpikir tradisional ke cara berpikir ilmiah (modern). Pendidikan mempunyai tugas menyiapkan sumber daya manusia untuk pembangunan. Derap langkah pembangunan selalu diupayakan seirama dengan tuntutan zaman. Perkembangan zaman selalu memunculkan persoalan-persoalan baru yang tidak pernah terpikirkan sebelumnya.

Namun hingga kini, upaya pemerintah untuk menangani permasalahan pendidikan di Indonesia, terutama pendidikan dasar dirasakan masih belum tuntas. Hal tersebut dibuktikan dengan setiap bergantinya rezim pemerintahan, utamanya dengan bergantinya menteri pendidikan, selalui diikuti dengan bergantinya kurikulum pendidikan. Dari sini tampak bahwa pemerintah masih belum menemukan bentuk pengelolaan pendidikan yang tepat bagi anak-anak kategori usia pendidikan dasar dan masih mencari-cari bentuk yang sesuai dengan kondisi masyarakat Indonesia sesuai dengan perkembangan ilmu pengetahuan dan teknologi.

Peran pemerintah sangat penting dalam dunia pendidikan, pemerintash menata pendidikan menuju otonomi daerah dengan cara profesionalisme guru, memperbaiki kualitas dan gaji guru, perbaikan fasilitas pendidikan dan membangun siswa yang berkualitas serta memberikan perhatian serius terhadap pengentasan putus sekolah bagi anak-anak yang tidak mampu mengakses pendidikan secara proporsional.

Sejalan dengan hal tersebut, maka menurut data Survei Sosial Ekonomi Nasional (Susenas) 2003 dari 42 juta anak usia $7-18$ tahun, $64,5 \%$ pendidikan tertinggi SD, $35,5 \%$ SMP, dan 16,8\% SMA. Menurut Prof. Beeby (2007) sebab terbesar anak Indonesia tidak bersekolah adalah kemiskinan, budaya orang tua, dan sekolah yang tidak menyenangkan. Menurut data Susenas 2003 alasan utama anak tidak sekolah $67 \%$ adalah ketidaktersediaan biaya dan $8,7 \%$ membantu orang tua mencari nafkah. Ketidak sanggupan membayar sekolah tersebut meliputi tidak sanggup membayar SPP bulanan, uang seragam, dan uang buku.

Dengan adanya pendidikan gratis, semua masalah pun dapat teratasi. Selain itu, pendidikan gratis juga tidak lepas dari peran serta pemerintah daerah karena pemerintah daerahlah yang mengaplikasikannya. Selain itu juga jika ada aturan yang jelas tentang program wajib belajar, maka tidak ada satupun orangtua yang membiarkan anaknya tidak bersekolah, serta pemerintah dapat memberi sanksi terhadap orangtua yang tidak menyekolahkan anak pada usia wajib belajar. 
Perbaikan fasilitas pendidikan.Sarana fisik sekolah seperti yang kita ketahui bersama banyak sekolah dasar khususnya dipelosok-pelosokyangtidakterurus dantidak tertata serta tidak memiliki sarana yang memadai. Padahal sekolah merupakan tempat untuk menimba ilmu guna menghadapi masa depan.Sekolah juga dipercaya sebagai dasar yang baik bagi pengembangan manusia.Pemerintah memperhatikan fasilitas pendidikan seperti rehabilitasi gedung-gedung sekolahyang rusak dan pembangunan gedung baru yang permanen. Begitu juga ruang belajar dibuat agar anak didik bisa merasa nyaman dalam belajar.

Membangun siswa yang berkualitas. Pemberdayaan peserta didik diarahkan dalam rangka melahirkan siswa ideal yakni siswa yang kreatif, inovatif dan mandiri. Beasiswa pendidikan ini hendaknya diprioritaskan kepada para siswa ekonomi lemah (miskin) namun berpotensi dan cerdas. Beasiswa pendidikan juga bermakna pemerataan dan perluasan kesempatan belajar karena masih banyak resistensi sebagian masyarakat untuk memasukkan anaknya pada lembaga- lembaga pendidikan dasar karena alas an ekonomi, belum semua masyarakat mendapat layanan pendidikan dasar secara optimal, khususnya di daerah terpencil, terisolir, kumuh, dan kawasan konflik.

Upaya pemerintah dalam memberdayakan peserta didiknya, baik melalui perbaikan sarana fisik sekolah, peningkatan mutu pembelajaran dan beasiswa. Peran serta pemerintah sangat besar terhadap dunia pendidikan karena pemerintah sedang menginvestasikan anakanak kita untuk menjadi pribadi yang mandiri, kreatif, dan inovatif yang akan mampu membawa kemajuan bagi bangsanya kelak dikemudian hari.

Peranan pemerintah dalam rangka pemberdayaan masyarakat pada bidang pengentasan anak putus sekolah memegang peranan penting dalam meningkatkan kualitas pendidikan anak-anak Indonesia.Dalam hal ini,pemerintah berperan dalam otonomi pendidikan.Dalam otonomi pendidikan keterlibatan pemerintah dalam pendidikan adalah mencakup aspek mutu dan pemerataan. Pemerintah menetapkan standar mutu pendidikan dan akan berupaya agar keragaman prestasi siswa tidak berbeda jauh pada setiap lembaga pendidikan.

Pemerintah menjamin pemerataan kesempatan bagi seluruh lapisan masyarakat untuk mendapatkan pendidikan. Peran ini dilakukan melalui perumusan kebijakan umum, pelayanan teknis, dan monitoring program secara regular. Perubahan peran ini mengubah hirarki pengambilan keputusan yang selama ini selalu berawal dari pemerintah pusat dan bermuara ke sekolah-sekolah. Adanya otonomi pendidikan hirarki pengambilan keputusan berubah menjadi piramida terbalik, yaitu kedudukan sekolah berada di atas, sedangkan lembaga pemerintah berada di bawah.

Sehubungan dengan deskripsi peranan pemerintah dalam pembedyaan masyarakat untuk megentaskan anak putus sekolah, secara emperik terlihat bahwa ada kecenderungan belum dijalankan secara efektif dan proporsional sebagaimana yang diamanatkan dalam UU Sisdiknas Nomor 20 tahun 2003. Dengan demikian, maka dapat diungkapkan beberapa indicator yang diduga sebagai entry point yang menyebabkan belum efektifnya peranan pemerintah daerah dalam hal ini Dinas Pendidikan Nasional dan Dinas Pemberdayaan Masysrakat Kabupaten Sidenreng Rappang dalam rangka memberdayakan masyaraka, khususnya mengentaskan anak putus sekolah di Kecamatan MaritengngaE, yaitu:(1) Ketersediaan gedung fisik sekolah belum memadai;(2) Ketersediaan biayaoperasional proses pembelajaran atau pendidikan belum memadai; dan (3) Ketersediaan SDM pendidikan yang professional belum memadai. Berdasarkan perspektif terhadap kecenderungan belum efektifnya peranan pemerintah dalam memberdayakan masysrakat khususnya pengentasan anak putus sekolah diKecamatan

MaritengngaE,makapenelitibermaksud untuk melakukan penelitian tentang hal tersebut sebagai upaya untuk mendapatkan solusiatas permasalahan pemberdayaan masyarakat dibidang pendidikan dengan mengangkat judul "Anakisis Peranan Pemerintah terhadap Pemberdayaan Masyarakt (Studi kasus Pengentasan Anak 
Putus Sekolah di Kecamatan Maritengngae) dengan tujuan Untuk mengetahui pengaruh Peranan Pemerintah Daerah terhadap pemberdayaan masyarakat mengentasan anak putus sekolah di Kecamatan MaritengngaE Kabupaten Sidenreng Rappang dan unutk mengetahui pemberdayaan masyarakat dalam mengentasan anakputus sekolah diKecamatan MaritengngaE Kabupaten Sidenreng Rappang

\section{Konsep Pendidikan}

Pendidikan merupakan salah satu faktor yang paling mendasar dalam siklus kehidupan manusia mulai lahir hingga akhir hayat (long life education). Secara teori, Pendidikan adalah usaha sadar dan terencana untuk mewujudkan suasana belajar dan proses pembelajaran agar peserta didik secara aktif mengembangkan potensi dirinya untuk memiliki kekuatan spiritual keagamaan, pengendalian diri, kepribadian, kecerdasan, akhlak mulia, serta keterampilan yang diperlukan dirinya, masyarakat, bangsa dan Negara (UU Sisdiknas, $2003: 1$ ).

Pendidikan merupakan suatu wahana di mana kita dapat mengetahui berbagai ilmu pengetahuan dan tata cara hidup berkualitas, sehingga kita dapat tumbuh menjadi manusia yang dapat berfikir untuk jangka panjang dan cerdas membangun bangsa. Oleh karena itu setiap manusia mempunyai hak untuk mendapatkan akses pendidikan yang memungkinkannya memiliki kesadaran kritis dalam menyikapi dinamika dan fenomena yang terjadi di masyarakatnya (Haditomo. 2002: 81)

Pendidikan merupakan kebutuhan sepanjang hayat. Setiap manusia membutuhkan pendidikan, sampai kapan dan dimanapun ia berada. Pendidikan sangat penting artinya, sebab tanpa pendidikan manusia akan sulit berkembang dan bahkan akan terbelakang. Dengan demikian pendidikan harus betul-betul diarahkan untuk menghasilkan manusia yang berkualitas dan mampu bersaing, di samping memiliki budi pekerti yang luhur dan moral yang baik.

Pendidikan dasar menurut UndangUndang Sisdiknas tahun 2003 adalah program pendidikan minimal yang harus diikuti oleh warga negara Indonesia atas tanggung jawab pemerintah dan pemerintah daerah. Pendidikan dasar yang dimaksud adalah pendidikan 12 tahun, ini berarti pendidikan minimal yang harus dimiliki adalah tingkat SD dan SMA dimana anak berusia tujuh sampai delapan belas tahun. Selain itu juga pemerintah dituntut untuk mengalokasikan minimal 20\% dari Anggaran Pendapatan dan Belanja Negara (APBN) untuk sektor pendidikan.

\section{Peranan Pemerintah dalam Pendidikan}

Menurut pandangan Hamalik Umar (2002: 100) bahwa peran pemerintah sangat penting dalam dunia pendidikan. Pemerintah menata pendidikan menuju otonomi daerah dengan cara menata profesionalisme guru, permasalahan profesionalisme guru, memperbaiki kualitas dan gaji guru, perbaikan fasilitas pendidikan serta membangun siswa yang berkualitas.

a. Menata profesionalisme guru pengembangan sumber daya manusia saat ini sedang digiatkan oleh berbagai pihak,baik lembaga-lembaga non pemerintahan maupu nmasyarakat luas.Tentu,ketika membicarakan SDM tidak bisa dipisahkan dari tenaga-tenaga yang menghasilkan SDM itu sendiri yakni guru.

b. Permasalahan profesionalisme guru Citraprofesi guru masih tersisih dibanding kanprofesilain seperti dokter,insinyur,pegawai swasta.Karena gaji guru paling rendah dibandingkan gaji profesi lainnya. Permasalahan rendahnya gaji guru dan berbagai persoalan yang membuntutinya dipastikan berakibat pada lamban dan tidak profesionalnya kinerja guru.Banyak saja guru yangpagihari mengajar sore atau malam hari dilakukan untuk kerja sampingan. Profesionalisme guru yang demikian akan berdampak negative kepada suasana proses belaja rmengajar yang tidak kondusif.

c. Memperbaiki kualitas dan gaji guru Citra profesi guru haruslah diperbaiki, guru harus mampu mengembangkan SDM karena guru sebagai seseorang yang digurui dan ditiru, didengar dan dicontoh. Guru harus mempunyai keleluasan untuk memberikan materi yang akan diberikan harus sesuai dengan kemampuan peserta didik dan tuntutan masyarakat. Guru juga harus mampu menciptakan suasana pembelajaran yang interaktif dan hidup. 
d. Perbaikan fasilitas pendidikan. Sarana fisik sekolah seperti yang kita ketahui bersama banyak sekolah dasar khususnya dipelosok-pelosok yang tidak terurus dan tidak tertata serta tidakmemiliki sarana yang memadai. Padahal sekolah merupakan tempat untuk menimba ilmu guna menghadapi masa depan.Sekolah juga dipercaya sebagai dasar yangbaik bagi pengembangan manusia.

e. Membangun siswa yang berkualitas. Pemberdayaan peserta didik diarahkan dalam rangka melahirkan siswa ideal yakni siswa yang kreatif, inovatif dan mandiri. Beasiswa pendidikan ini hendaknya diprioritaskan kepada para siswa ekonomi lemah (miskin) namun berpotensi dan cerdas.

Upaya pemerintah dalam memberdayakan pesertadidiknya,baik melalui perbaikan sarana fisik sekolah,peningkatan mutu pembelajaran dan beasiswa. Peran serta pemerintah sangat besar terhadap dunia pendidikan karena pemerintah sedang menginvestasikan anak-anak kita untuk menjadi pribadi yang mandiri, kreatif,dan inovatif yang akan mampu membawa kemajuan bagi bangsanya kelak dikemudianhari (Koeswara,2006:59).

\section{Pemberdayaan Masyarakat Bidang Pendidikan}

Undang-undang telah mengamanatkan kepada pemerintah,untuk memperhatikan pendidikan. Namun kenyataan sekarang,belum ada langkah nyata dari pemerintah.Sedikit sekali pemerintah kota/ kabupatan yang peduli terhadap amanat undang-undang. Menurut data Balitbang Departemen Pendidikan Nasional berkaitan dengan analisis Biaya Satuan Pendidikan (BSP) untuk pendidikan dasar dan menengah, biaya yang dikeluarkan meliputi: (1) Buku dan alat tulis; (2) Pakaian dan perlengkapan sekolah; (3) Akomodasi; (4) Transportasi; (4) Konsumsi; (5) Kesehatan; (6) Karyawisata; (7) Uang saku; (8) Kursus; (9) Iuran sekolah; dan (10) Pembelajaran terdahulu. Undang-undang mengamanatkan agar pemerintah memperhatikan anak-anak usia sekolah agar dapat mengikuti pendidikan dasar tanpa dibebani biaya yang dapat menghambat proses pendidikan. Hal ini dipertegas dalam Undang-Undang Sisdiknas Nomor 20 tahun 2003 pasal 11 ayat2 yang berbunyi "Pemerintah dan pemerintah daerah wajib menjamin tersedianya dana guna terselenggaranya pendidikan bagi setiap warga negara yang berusia tujuh sampai lima belas tahun"

Dengan wajib belajar, mereka
akan dapat menjalani hidup dan menghadapi kehidupan dalam masyarakat. Untuk itu, target penyelenggaraan W-9-T bukan semata-mata untuk mencapai target angka partisipasi secara maksimal, namun perhatian yang sama ditujukan juga untuk memperbaiki kualitas pendidikan dasar yang sekarang ini masih jauh dari standar nasional.

\section{Pengentasan Anak Putus Sekolah}

Secara nasional, tujuan pendidikan diletakkan pada tiga pilar, yaitu (1) pemerataan kesempatan dan perluasan akses; (2) peningkatan mutu, relevansi, dan daya saing; (3) penguatan tata kelola, akuntabilitas, dan pencitraan publik. Pilar Pemeratan kesempatan dan perluasan akses merupakan salah satu upaya meningkatkan kualitas sumber daya manusia melalui penciptaan dan peningkatan layanan pendidikan kepada seluruh warga negara.Akibat putus sekolah dalam kehidupan sosial ialah semakin banyaknya jumlah kaum pengangguran dan mereka merupakan tenaga kerja yang tidak terlatih. Sedangkan masalah pengangguran ini di negara kita merupakan masalah yang sudah sedemikian hebatnya, hingga merupakan suatu hal yang harus ditangani lebih serius. Anak-anak yang putus sekolah dapat pula mengganggu keamanan. Karena tidak ada kegiatan yang menentu, sehingga kadangkadang dapat menimbulkan kelompokkelompok pemuda liar.

Hanya dengan generasi penerus yang terdidik dan cerdas serta bermoral, maka hari depan bangsa bisa dibayangkan titik terangnya. Namun pendidikan di Indonesia semakin lama semakin mahal. Program pendidikan gratis yang diterapkan pemerintah pun masih dianggap belum efektif dalam meningkatkan pendidikan di Indonesia.Sekolah Faktor penyebab yang dimaksudkan adalah hal-hal yang menyebabkan anak putus sekolah. Berikut dipaparkan beberapa faktor penyebab anak tidak dan putus sekolah. Antara lain penyebab anak yang putus sekolah dikarenakan oleh beberapa faktor, yaitu: (a) ekonomi, minat anak yang kurang perhatian 
orangtua rendah;(b) faktor budaya;(c)fasilitas belajar kurang;(d)ketiadaan sekolah/sarana; dan(e)cacat atau kelainan jiwa.

a. Faktor Ekonomi yang menyebabkan anak tidak dan putus sekolah adalah factor ekonomi. Fakto rekonomi yang dimaksudkan adalah ketidakmampuan keluarga si anak untuk membiayai segala proses yang dibutuhkan selama menempuh pendidikan atau sekolah dalam satu jenjang tertentu. Walaupun Pemerintah telah mencanangkan wajib belajar 12 tahun, namun belum berdampak secara maksimal terhadap penurunan jumlah anak yang tidak danputus sekolah.

b. Faktor Kurangnya Minat yang menyebabkan anak tidak dan putus sekolah adalah rendahnya atau kurangnya minat anak untuk bersekolah, Rendahnya minat anak dapat disebabkan oleh perhatian orang tua yang kurang, jarak antara tempat tinggal anak dengan sekolah yangj auh,fasilitas belajar yang kurang,dan pengaruh lingkungan sekitarnya.Minat yang kurang dapat disebabkan oleh pengaruh lingkungan misalnya tingkat pendidikan masyarakat rendahy ang diikuti oleh rendahnya kesadaran tentang pentingnya pendidikan.

c. Faktor Kurangnya Perhatian Orang Tua adalah kurangnya perhatian orang tua.Rendahnya perhatian orang tua terhadap anak dapat disebabkan karena kondisi ekonomi keluarga atau rendahnya pendapatan orangtua si anak sehingga perhatian orang tua lebih banyak tercurah pada upaya untuk memenuhi kebutuhan keluarga.

d. Faktor Ketiadaan Prasarana Sekolah yang dimaksudkan adalah terkait dengan ketidak tersediaan prasarana pendidikan berupa gedung sekolah atau alat transportasi dari tempat tinggal siswa dengan sekolah.

e. Faktor Fasilitas Belajar Kurang Memadai yang dimaksudkan adalah fasilitas belajar yang tersedia di sekolah,misalnya

perangkat(alat,bahan, danmedia)pembelaj aran yang kurang memadai, buku pelajaran kurang memadai,dan sebagainya.Kebutuhan dan fasilitas belajar yang dibutuhkan siswa tidak dapatdipenuhi siswa dapat menyebabkan turunnya minat anak yang pada akhirnya menyebabkan putus sekolah.

f. Faktor Budaya yang dimaksudkan disini adalah terkait dengan kebiasaan masyarakat disekitarnya,yaitu rendahnya kesadaran orang tua atau masyarakat akan pentingnya pendidikan.

g. Faktor lainnya,adalah cacat ,IQ yang rendah,rendah diri,dan umur yang melampaui usia sekolah.Persentase anak yang putus sekolah yang disebabkan karena factor ini sangat sedikit,yaitu kurang dari $1 \%$.Begitu juga untuk kategori anak tidak sekolah sama sekali,factor penyebabnya adalah karena ekonomi disamping factor sarana, minat yang kurang,perhatian orangtua yang rendah,dan fasilitas yang kurang.

\section{B. METODE PENELITIAN}

Jenis Penelitian yang digunakan adalah pendekatan deskriftif kuantitatif, yang bermaksud untuk mengkaji dan menganalisis indikator variable pengaruh peranan pemerintah daerah terhadap pemberdayaan masyarakat pengentasan anak putus sekolah di Kecamatan Maritengngae Kabupaten Sidrap. Populasi dalam penelitian ini berjumlah 65 orang, dengan rincian sebagai berikut: (1) Dinas Pendidikan Nasional Kabupaten Sidenreng Rappang sebanyak 25 orang; dan (2) Dinas Pemberdayaan Masysrakat Kabupaten Sidenreng Rappang sebanyak 20 orang; dan (3) Pendidik 20 orang. Karena populasi hanya 65 orang (kurang dari 100 orang), maka Penulis mengambil keseluruhan populasi tersebut sebagai sampel dan sekaligus ditetapkan sebagai responden. Selanjutnya untuk memperoleh data yang akurat, relevan dan dapat dipertanggung jawabkan maka penulis menggunakan bebrapa teknik dalam mengumpulan data sebagai berikut: Kuesioner, Dokumentasi, Observasi sedangkan Teknik analisis data yang digunakan yaitu analisis data dengan table frekuensi dan persentase, dengan menggunakan bobot penilaian pertanyaan Skala Litkert, yaitu: (1) sangat baik diberi nilai 5; (2) cukup baik diberi nilai 4; (3) baik diberi nilai 3; (4) kurang baik diberinilai 2; dan (5) tidak baik diberi nilai 1 . 


\section{HASIL DAN PEMBAHASAN}

Upaya pemerintah untuk menangani permasalahan pendidikan di Indonesia, terutama pendidikan dasar dirasakan masih belum tuntas. Hal tersebut dibuktikan dengan setiap bergantinya rezim pemerintahan. Dari sini tampak bahwa pemerintah masih belum menemukan bentuk pengelolaan pendidikan yang tepatbagi anakanak kategori usia pendidikan dasar dan masih mencari-cari bentuk yang sesuai dengan kondis imasyarakat Indonesia sesuai dengan perkembangan ilmu pengetahuan dan teknologi.

Dari data yang diperoleh penulis melalui kuesioner tentang Analisis Peranan Pemerintah Daerah Terhadap Pemberdayaan Masyarakat dalam Pengentasan Anak Putus Sekolah di Kecamatan MaritengngaE Kabupaten Sidenreng Rappang dapat dilihat pada tabel berikut ini:

\section{Persiapan Sarana dan Prasarana untuk pelasanaan Pembelajaran (Gedung Sekolah).}

Tanggapan Responden tentang Persiapan Sarana dan Prasarana untuk pelasanaan

Pembelajaran(GedungSekolah).sekolah adalah 52 orang $(80 \%)$ responden menjawab Sangat Setuju, 13 orang (20\%) responden menjawab Setuju,dan tidak ada responden yang menjawab tidak setuju begitupula sangat tidak setuju. Jadi setelah diakumulasikan dan didapatkan nilai ratarata presentase tanggapan Responden tentang Tanggapan Responden tentang Persiapan Sarana dan Prasarana untuk pelaksanaan Pembelajaran (Gedung Sekolah) adalah 95\% yang dengan kategori Sangat Setuju. Semua responden setuju dengan adanya sekolah-sekolah sebagai salah satu upaya pemerintah dalam pengentasan anak putus sekolah walaupun masih ada daerah-daerah yang jauh dari jangkauan masyarakat.

\section{Biaya Operasional yang diperuntukan dalam pelaksanaan pendidikan}

Tanggapan Responden tentang

Tanggapan Respondententang Biaya Operasional yang diperuntukan dalam pelaksanaan pendidikan. sekolah adalah 12 orang $(12,47 \%)$ respondenmenjawab SangatSetuju,41 orang(63,08\%) responden menjawab Setuju,8 orang $(12,3)$ respon dan yang menjawab tidak setuju,dan 4 orang $(6,15)$ responden yang menjawab sangat tidak setuju. Jadi setelah diakumulasikan dan didapatkan nilai ratarata presentase tanggapan Responden tentang Biaya Operasional yang diperuntukan dalam pelaksanaan pendidikan adalah73,5\% dengan kategori Sangat Setuju. Adapun responden yang tidak setuju maupun sangat tidak setuju dikarenakan banyak masyarakat yang tidak tau atau tidak merasakan adanya bantuan pemerintah mengenai biaya operasional.

\section{Pemberdayaan Sumber Daya Manusia yaitu tenaga Pendidik dalam pelaksanaan pembelajaran}

Tanggapan Responden tentang Pemberdayaan Sumber Daya Manusia yaitu tenaga Pendidik dalam pelaksanaan pembelajaran. sekolah adalah 17orang $(26,15 \%)$ responden menjawab Sangat Setuju,39 orang $(60 \%)$ responden menjawab Setuju, 7 orang $(10,77 \%)$ responden yang menjawab tidak setuju,dan 2 orang (3,08\%) responden yang menjawab sangat tidak setuju. Jadi setelah diakumulasikan dan didapatkannilai rata-rata presentase tanggapan Responden tentang Pemberdayaan Sumber Daya Manusia yaitu tenaga Pendidik dalam pelaksanaan pembelajaran adalah $77,25 \%$ yang berarti kategori Setuju. Responden yang merespon dengan tidak setuju bahkan sangat tidak setuju dikarenakan ditempat anak mereka sekolah beranggapan bahwa tenaga didik Yang ada disekolah tersebut belum memenuhi persyaratan sebagai pendidik yang baik untuk mendidik anak mereka.

\section{Pemberian bantuan berupa Pendidikan Gratis bagi yang tidak mampu mengakses Pendidikan Formal}

Tanggapan Responden tentang Pemberdayaan Sumber Daya Manusia yaitu tenaga Pendidikdalam pelaksanaan pembelajaran. sekolah adalah 35 orang $(53,85 \%)$ responden menjawab Sangat Setuju,30 orang $(46,15 \%)$ responden menjawab Setuju, sementara tida ada responen yang menjawab tidak setuju maupun sangat tidak setuju. Jadi setelah diakumulasikan dan didapatkan nilai ratarata presentase tanggapan Responden tentang Pemberian bantuan berupa 
Pendidikan Gratis bagi yang tidak mampu mengakses Pendidikan Formal adalah $88,5 \%$ yang berarti kategori setuju.

\section{Program Wajib belajar 12 tahun untuk meningkatan dan mengembangan SDM dalam bidang Pendidikan}

Tanggapan Responden tentang

Program Wajib belajar 12 tahun untuk meningkatan dan mengembangan SDM dalam bidang Pendidikan adalah 14 orang $(21,54 \%)$ responden menjawab Sangat Setuju,23 orang (35,38\%) responden menjawab Setuju, 19 orang $(29,23 \%)$ responden yang menjawab tidak setuju,dan 9 orang $(13,85 \%)$ responden yang menjawab sangat tidak setuju.

\section{Tanggapan Responden tentang Program Wajib belajar 12 tahun untuk meningkatan dan mengembangan SDM dalam bidang Pendidikan}

Tanggapan

Responden

tentangProgram Wajib belajar 12 tahun untuk meningkatan dan mengembangan SDM dalam bidang Pendidikan adalah 14 orang $(21,54 \%)$ responden menjawab Sangat Setuju,23 orang $(35,38 \%)$ responden menjawab Setuju,19 orang (29,23\%) responden yang menjawab tidak setuju,dan 9 orang $(13,85 \%)$ responden yang menjawab sangat tidak setuju. Jadi setelah diakumulasikan dan didapatkan nilai ratarata presentase tanggapan Responden tentang Program Wajib belajar 12 tahun untuk meningkatan dan mengembangan SDM dalam bidang Pendidikan adalah $66,25 \%$ yang berarti kategori Setuju. Adapun alasan-alasan responden yang tidak setuju dan sangat tidak setuju dengan program belajar wajib 12 tahun yaitu: mereka beranggapan bahwa walaupun sampai 9 tahun masa belajar anak mereka sudah bisa diandalkan dalam membantu pekerjaan mereka,misalkan bertani.Jadi anak yangs udah bisa baca tulis dan tenaga mereka sudah bisa membantu pekerjaan orang tua.

7. Pengentasan anak putus sekolah merupakan akses kepada anak yang kurang mampu.

Tanggapan Responden tentang Pengentasan anak putus sekolah merupakan akses kepada anak yang kurang mampu adalah 15 orang (23,08\%) responden menjawab Sangat Setuju,36 orang $(55,38 \%)$ responden menjawab Setuju,12 orang $(18,46 \%)$ responden yang menjawab tidak setuju,dan 2 orang $(3,08 \%)$ responden yang menjawab sangat tidak setuju. Jadi setelah diakumulasikan dan didapatkan nilai rata-rata presentase tanggapan Responden tentang Pengentasan anak putus sekolah merupakan akses kepada anak yang kurang mampu adalah $74,5 \%$ yang berarti kategori Setuju.

\section{Usaha pemerintah terhadap peningatan SDM.}

Tanggapan Responden tentang Pengentasan anak putus sekolah merupakan akses kepada anak yang kurang mampu adalah 12 orang (18,46\%) responden menjawab Sangat Setuju,42 orang $(64,62 \%)$ responden menjawab Setuju, 7 orang $(10,77 \%)$ responden yang menjawab tidak setuju,dan 4 orang $(6,15 \%)$ responden yang menjawab sangat tidak setuju. Jadi setelah diakumulasikan dan didapatkan nilai rata-rata presentase tanggapan Responden tentang usaha pemerintah terhadap peningatan SDM adalah $74,5 \%$ yang berarti kategori setuju.

\section{KESIMPULAN}

Berdasarkan uraian-uraian serta pembahasan pada bab terdahulu maka penulis mencoba menarik kesimpulansebagai berikut:

1. Peranan Pemerintah Daerah terhadap pemberdayaan masyarakat mengentasan anak putus sekolah di Kelurahan Pangkajene Kecamatan Maritenggae Kabupaten Sidenreng Rappang dalam penelitian ini memperoleh nilai $77,25 \%$ dan berada pada kategori berperan.

2. Faktor yang mempengaruhi Peranan Pemerintah Daerah terhadap pemberdayaan masyarakat mengentasan anak putus sekolah diKelurahan Pangkajene Kecamatan Maritengngae Kabupaten Sidenreng Rappang dalam penelitian ini memperoleh nilai $73 \%$ dan berada pada kategori berpengaruh.

\section{E. REFERENSI}

Bebby.2007.HumanAggressionASocialPsych ologiAnalysis. McGrowHillBookCompany,NewYork. 
Haditomo. 2002. Psikologi Perkembangan.

Gajah Mada University

Press.Yogyakarta.

Hamalik Umar. 2002. Pendidikan Guru Berdasakan Pendekatan

Kompetansi.BumiAksara.Jakarta

Koeswara,2006. AgresiManusia.PT. Eresco. Bandung

Sugiono.2002.MetodePenelitianKualitatifdanK uantitatif. Alfabet.Bandung

Undang-UndangDasarRITahun1945.

Undang RI Nomor 20 tentang Sisdiknas 2003. Fokus media. Bandung 